\title{
Recent reduction in the frequency of frost accounts for most of the increased growth of a high elevation spruce forest in northwestern China
}

\author{
Richard H. Waring ${ }^{1} \cdot$ Linlin Gao ${ }^{2}$
}

Received: 2 September 2015/Accepted: 20 January 2016/Published online: 16 February 2016

(C) The Author(s) 2016. This article is published with open access at Springerlink.com

\begin{abstract}
Key message Using process-based models in combination with dendrochronological measurements provides a way to explain recent increased tree growth in northwestern China.

Abstract Dendrochronological studies of tree rings in a 250-year-old Qinghai spruce (Picea crassifolia) forest in the Qilian Mountains of northwestern China indicate a $60 \%$ sustained increase in tree-ring growth between 1980 and 2009 compared with any time since 1785 . Over the same period, the maximum, minimum, and average temperatures all increased by nearly $2{ }^{\circ} \mathrm{C}$ during the growing season (May through September), the frequency of frost decreased 18 days, precipitation remained unchanged, while atmospheric concentrations of $\mathrm{CO}_{2}$ increased by $48 \mathrm{ppm}$. To explain how the changes in climatic variables might cause the increase in tree growth, we parameterized a process-based growth model (3-PG, physiological processes predicting growth) with values from the literature and performed a series of sensitivity tests. The results of our analysis indicated that a reduction in frost frequency during the growing season, which allows stomata to remain open, enhanced gross photosynthesis by $42 \%$. Up to a $20 \%$ increase in $P_{\mathrm{G}}$ could be attributed to rising atmospheric $\mathrm{CO}_{2}$ between 1980 and 2009, with half of this
\end{abstract}

Communicated by G. Wieser.

Richard H. Waring

richard.waring@oregonstate.edu

1 Department of Forest Ecosystems and Society, Oregon State University, Corvallis, OR 97331, USA

2 Key Laboratory of Western China's Environmental Systems, School of Earth and Environmental Sciences, Lanzhou University, Lanzhou 73000, China attributed to increased light interception from a simulated 0.4 increase in canopy leaf area index. The increase in average and maximum temperatures had little direct effect on gross photosynthesis with the optimum temperature set between 9 and $10{ }^{\circ} \mathrm{C}$. Indirectly, the increase in monthly average minimum temperature during the growing season, although small, crossed a threshold that reduced the impact of frost. Our analyses show the value of combining dendrochronological measurements with a process-based model to gain a more holistic understanding of how environmental factors interact to affect tree growth.

Keywords Process-based model $\cdot 3$-PG $\cdot$ Qinghai spruce $\cdot$ Tree-ring analysis $\cdot$ Frost $\cdot$ Atmospheric $\mathrm{CO}_{2}$

\section{Introduction}

Forests at high elevations, where only a few species are adapted to such a harsh environment, are particularly susceptible to climate change. In such places, gradual changes in climate may cross thresholds that cause rapid changes in tree growth, as well as increased susceptibility to attack from insects and pathogens (Raffa et al. 2008; Bentz et al. 2010; Yan and Niu 2008; Ayres and Lombardero 2000; Sturrock et al. 2011).

Dendroclimatic studies have contributed much to the interpretation of past climatic conditions through statistical correlations between ring widths and annual and seasonal patterns in precipitation and temperature. For example, Salzer et al. (2009) report that high elevation Great Basin bristlecone pine (Pinus longaeva) at three sites in western North America showed ring growth in the second half of the 20th century that was greater than during any other 50-year period in the last 3700 years. A similar 
unprecedented increase in growth over a 425-year chronology was reported in Juniperus przeqalskii from the Xiqing Mountains in northeast Tibet in association with an increase in minimum winter temperature of $2.5^{\circ} \mathrm{C}$ (Gou et al. 2007). In an analysis of 225-year-old Qinghai spruce (Picea crassifolia) growing at $3200 \mathrm{~m}$ elevation in the eastern Qilian Mountains of northwestern China, Gao et al. (2015) reconstructed a warming trend during July that began around 1900 and has continued, with eight of the ten warmest Julys recorded during the period 1990-2009. There was no indication that variation in precipitation had any effect on growth over the last 53 years.

Atmospheric concentrations of $\mathrm{CO}_{2}$ now exceed $400 \mathrm{ppm}$, and minimum temperatures are increasing asymmetrically compared with the maximum (Walther et al. 2002). As a consequence of these rapid asymmetrical changes, statistical correlations of growth with basic weather data are becoming less reliable (Briffa et al. 1998; Gao et al. 2013) and much more variable (Zhang and Wilmking 2010). As an alternative to conventional dendrochronological analysis, process-based modeling may offer a more holistic interpretation (Evans et al. 2006).

Process-based models offer an alternative means of evaluating growth responses because, unlike statistical models, they include functions that define thresholds to constrain photosynthesis, transpiration, and growth and do not require site-by-site tuning (Evans et al. 2006). Li et al. (2014) applied a process-based model to predict the growth of individual Pinus koraiensis trees in one stand located in the Changbai Mountains in northeastern China.

We took advantage of the tree-ring analysis performed by Gao et al. (2015) on Qinghai spruce to apply a processbased model to assess environmental factors that might explain such a rapid increase in growth between 1980 and 2009 compared with the period 1957-1979. We found sufficient information in the literature to parameterize such a model for $P$. crassifolia, along with methods to derive estimates of incident solar radiation, evaporative demand, and the frequency of frost from conventional weather records (Running et al. 1987).

In this paper, we use a process-based growth model, 3-PG, (physiological principles predicting growth) model developed by Landsberg and Waring (1997) to assess the relative importance of different environmental factors alone, and in concert, that might account for a recent sustained increase in tree-ring growth between 1980 and 2009. We ran simulations with 3-PG model to assess the relative importance of three factors on tree growth: (1) a $48 \mathrm{ppm}$ rise in the concentration of atmospheric $\mathrm{CO}_{2},(2)$ a nearly $2{ }^{\circ} \mathrm{C}$ increase in mean, maximum, and minimum temperatures for each month from May to September, and (3) a decrease of 18 days in the frequency of frost during the 5-month growing season.

\section{Materials and methods}

\section{Study site}

The Qilian Mountains are located on the northeastern margin of Qinghai-Tibet Plateau in northwestern China. Climatic conditions are typical of a continental highland with cold winters, a cool growing season, and sparse precipitation, most of which occurs in the summer. The study site $\left(37.9^{\circ} \mathrm{N}, 101.4^{\circ} \mathrm{E}\right.$ at an elevation of $3190-3210 \mathrm{~m}$ a.s.1.) is located in the Shiyang River Basin in the eastern Qilian Mountains (Fig. 1).

Qinghai spruce (P. crassifolia) is the dominant conifer in the Qilian Mountains. The spruce grows very slowly (12 m height at 100 years, Liu 1988), on north-facing or otherwise shaded slopes (Gao et al. 2015). The forests are generally open with a projected leaf area index $(L) \leq 3.0 \mathrm{~m}^{2} \mathrm{~m}^{-2}$ (Tian et al. 2011). The soils at the study site are relatively deep (Gao et al. 2015) and classified as alpine forest gray-brown and subalpine shrub meadow types with a clay-loam texture (Nie et al. 2009).

\section{Climatic data}

Temperature and precipitation data from meteorological stations at Menyuan (elevation $2850 \mathrm{~m}$ ) and Qilian (elevation $2787 \mathrm{~m}$ ) were combined and averaged at monthly intervals according to procedures described by Jones and Hulme (1996) into one series over the period 1957-2009. To make the temperature data representative for the study site $(65-100 \mathrm{~km}$ distance from the meteorological stations), we decreased the previously derived temperature values by $0.6{ }^{\circ} \mathrm{C}$ per $100 \mathrm{~m}$ gain in elevation. We averaged

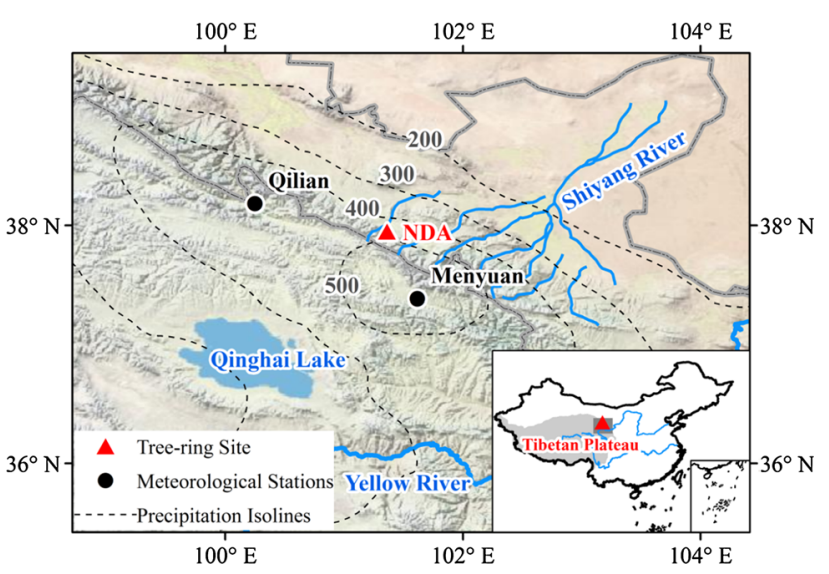

Fig. 1 Map showing the locations of the tree-ring sampling site (NDA, red triangle at $3200 \mathrm{~m}$ ) and the two nearest meteorological stations (black dots Qilian at $2790 \mathrm{~m}$ and Menyuan at $2851 \mathrm{~m}$ elevation). The dash lines indicate mean annual precipitation (100 mm year ${ }^{-1}$ contours) provided from the Tropical Rainfall Measuring Mission (TRMM) satellite for the period AD1998-2012 (Huffman et al. 2007). Map adapted from Gao et al. (2015) 
the precipitation data from both stations, although it is likely that values at the study site were slightly higher than recorded at either station (Gao et al. 2015).

To drive a process-based growth model, we derived incident solar radiation $\left(\phi_{\mathrm{par}}\right)$, mean daytime vapor pressure deficit $(D)$, and the frequency of frost $(F)$ per month. The mean daily incident solar radiation $(\sim 50 \%$ of which is photosynthetically active) was estimated from the difference between daily averaged maximum and minimum temperatures each month and knowledge of the latitude, elevation, slope, and aspect of the study site (Coops et al. 2000). The mean daytime vapor deficit $(D)$ for each month was estimated by assuming that the minimum temperature corresponds to the dewpoint temperature in most forested areas (Kimbell et al. 1997) and that $D$ was $2 / 3$ of the maximum value; the minimum temperature $\left(T_{\min }\right)$ served as a basis for predicting the frequency of frost $\left(<-2{ }^{\circ} \mathrm{C}\right)$ each month (Eqs. 1a, 1b) (Waring and McDowell 2002).

Days of frost per month $(F)=-2.0\left(T_{\min }\right)+11.6$

If $T_{\min } \leq-9{ }^{\circ} \mathrm{C}, F=30 ;$ if $T_{\min } \geq 6.0{ }^{\circ} \mathrm{C}, F=0$

\section{Tree-ring data}

Tree-ring growth data were acquired from dual increment cores extracted from 27 spruce trees at the study site. There were no missing rings for these series and reasonable interseries correlations $(r=0.65)$. All ring-width series, measured with a precision of $0.001 \mathrm{~mm}$, were included to develop the final chronology. The conventional straight lines or negative exponential curves were used to remove the age-related growth trend. The "signal-free" version of program ARSTAN served to calculate the standard treering chronology (Melvin and Briffa 2008; Cook et al. 2013). Additional details on the preparation and analysis of increment cores are presented in Gao et al. (2015).

\section{3-PG model}

There are a number of physiologically based process growth models to choose among (Mäkelä et al. 2000; Constable and Friend 2000). The 3-PG model differs from others primarily in a number of simplifying assumptions that: (1) monthly mean climatic data are adequate to capture major trends in forest growth; (2) autotrophic respiration $\left(R_{\mathrm{a}}\right)$ and net primary production $\left(P_{\mathrm{N}}\right)$ are approximately equal fractions of gross photosynthesis $\left(P_{\mathrm{G}}\right)$ (Campioli et al. 2015); and (3) the proportion of $P_{\mathrm{N}}$ allocated to roots increases from 25 to $80 \%$ as nutrients (particularly nitrogen) become progressively less available.
Beer's Law is among a number of biophysical principles embedded in the model. This law allows the model to estimate the fraction of visible radiation absorbed by the canopy as an exponential function (Eq. 2) of increasing $L$ (Campbell and Norman 1998).

$\phi_{\text {apar }=} 1-\exp ^{(-k L)}$

where $\phi_{\text {apar }}$ is absorbed photosynthetically active radiation (MJ m ${ }^{-2}$ month $\left.^{-1}\right), k$ is the extinction coefficient $(\sim 0.5$ for conifers), and $L$ is the (projected) leaf area index.

Gross photosynthesis, canopy evaporation and transpiration, growth allocation and litter production are also predicted at monthly intervals $(\Delta t)$ as functions of $L$ and $\phi_{\text {apar }}$. The model reduces potential photosynthesis and transpiration by imposing restrictions on stomatal conductance through modifiers $(f)$, taking values between $0=$ complete restriction and $1.0=$ no restriction. These modifiers combine (in Eq. 3) to account for the effects of frost, non-optimal temperatures, constraints imposed by the vapor pressure deficits, limitations in the availability of soil water and nutrients, and the effect of variation in atmospheric concentrations of carbon dioxide $\left(\mathrm{CO}_{2}\right)$.

$P_{\mathrm{G}}=P_{\text {Eff }} \phi_{\text {apar }} f(T) f(F) f(D) f\left(\theta_{s}\right) f(N) f\left(\mathrm{CO}_{2}\right)$

where $P_{\mathrm{G}}$ is gross photosynthesis $\left(\mathrm{gC} \mathrm{m}^{-2}\right.$ month $\left.^{-1}\right), P_{\mathrm{Eff}}$ is photosynthetic light-use efficiency expressed as $\mathrm{gC} \mathrm{MJ} \phi_{\mathrm{apar}}^{-1}, \phi_{\mathrm{apar}}$ is the photosynthetically active radiation absorbed by the canopy, $T$ represents any limitation imposed by deviation from optimum temperature $\left(T_{\text {opt }}\right), F$ is derived from the proportion of days $<-2{ }^{\circ} \mathrm{C}$ per month, $D$ is the constraint imposed by the daytime vapor pressure deficits in $\mathrm{kPa}, \theta_{\mathrm{s}}$ represents the extent that soil water deficits in the rooting zone restrict canopy stomatal conductance $\left(G_{\mathrm{c}}\right), N$ represents nutritional restrictions, and $\mathrm{CO}_{2}$ denotes the influence that variation in atmospheric carbon dioxide $(\mathrm{ppm})$ has on $P_{\text {Eff. We }}$ used Eq. (4a) to assess the effect of variation in atmospheric concentrations of $\mathrm{CO}_{2}$ based on data acquired at FACE studies (Ainsworth and Rogers 2007). Almeida et al. (2009) developed a related formula to predict the response of $G_{\mathrm{c}}$ with maximum canopy conductance $\left(G_{\max }\right)$ substituted for $P_{\text {Eff }}$ in Eq. (4b). The function $f\left(\mathrm{CO}_{2}\right)$ is calculated in reference to atmospheric concentrations of $350 \mathrm{ppm}$ and may be above or below unity. A similar response to rising concentrations of atmospheric $\mathrm{CO}_{2}$ affects water-use efficiency by reducing $G_{\max }$ (Eq. 4b). The equations predict that raising atmospheric $\mathrm{CO}_{2}$ levels by $72 \mathrm{ppm}$ from $315 \mathrm{ppm}$ in 1957 to $387 \mathrm{ppm}$ in 2009 should result in a $5.3 \%$ increase in $P_{\text {Eff }}$ and a $9.5 \%$ increase in $G_{\mathrm{c}}$. 
$f\left(\mathrm{CO}_{2}\right)$ as it modifies $P_{\text {Eff }}$ in Eq.3

$$
=0.2553 \ln \left(\mathrm{CO}_{2}\right)-0.4981
$$

$f\left(\mathrm{CO}_{2}\right)$ as it modifies $G_{\max }$ when solving for $G_{\mathrm{c}}$

$$
=-0.464 \ln \left(\mathrm{CO}_{2}\right)+3.7343
$$

The 3-PG model is programmed to reduce transpiration (and photosynthesis) to zero based on the number of frost days. This subfreezing threshold is sufficient to cause complete stomata closure for at least $24 \mathrm{~h}$ (Hadley 2000) and at times much longer (Lamontagne et al. 1998). The soil water modifier is determined from the ratio of the amount of water available in the root zone of the trees $\left(\theta_{\mathrm{s}}\right)$ to the maximum value $\left(\theta_{\max }\right) . \theta_{\max }$ is the water holding capacity of the soil, which is the difference between the water content in the root zone at field capacity and at the wilting point. For any given month, the available soil water $\left(\theta_{\mathrm{s}}\right)$ is calculated from:

$\theta_{s}(t+\Delta t)=\theta_{s}(t)+\left(P-E-T_{\text {rans }}\right)$

where $\theta_{\mathrm{s}}(t)$ is the value at the beginning of the month, $\Delta t$ represents the change, $P, E$ and $T_{\text {rans }}$ denote the monthly values of precipitation, evaporation and transpiration, respectively. The model includes a term to account for rainfall interception by the forest canopy; this water is assumed to be lost by evaporation, giving $E$. Transpiration is calculated from the Penman-Monteith equation (Monteith and Unsworth 1990), which incorporates a canopy conductance term derived from stomatal conductance and $L$. If the value of $\theta_{\mathrm{s}}$ on the left-hand side of Eq. (5) exceeds $\theta_{\max }$, i.e., the whole root zone is at field capacity, the excess is assumed to be lost as runoff or drainage.

At monthly time steps, the model is unable to compute a snow water balance accurately, although one may assume that precipitation in months with average temperatures well below freezing is largely in the form of snow. At annual time steps, the model sums monthly changes in tree number, mean diameter, stand basal area, above-ground volume and biomass and updates $L$. Without knowledge of stand characteristics, we assumed low stocking of 200 trees ha $^{-1}$ to prevent changes in number associated with self-thinning (Drew and Flewelling 1977), and kept maximum values of $L<3.0 \mathrm{~m}^{2} \mathrm{~m}^{-2}$ and monthly transpiration $<60 \mathrm{~mm}$ based on observations by Tian et al. (2011). Normally, as trees grow in height, hydraulic limitations are imposed on stomata that reduce the maximum rates of photosynthesis and transpiration (Brodribb and Field 2000; Warren and Adams 2000; Koch et al. 2004).

\section{Model parameterization}

We eliminated the self-thinning and age effect from our simulations by selecting a low stocking level $\left(200\right.$ trees $\mathrm{ha}^{-1}$ ) and by setting the maximum age at
1000 years to inactivate these subroutines (Table 1). Most of the other parameter values reported in Table 1 were derived from measurements made on $P$. crassifolia. Zhao et al. (2008) was particularly valuable in documenting that the concentration of nitrogen in spruce needles was extremely low (0.7-0.8\% of dry mass). With such a low value, soil fertility is unlikely to have changed over the period of study, and can be assumed to remain low (fertility ranking $=0.1)$, with light-use efficiency also low ( $0.03 \mathrm{~mol} \mathrm{C} / \mathrm{mol}$ photon, equivalent to $1.65 \mathrm{gC} / \mathrm{MJ}$ absorbed PAR). We were unable to fine measurements of the photosynthetic temperature optimum $\left(T_{\mathrm{opt}}\right)$, maximum $\left(T_{\max }\right)$ and minimum $\left(T_{\min }\right)$ for $P$. crassifolia, and substituted values reported for $P$. abies in the Austrian Alps (Tranquillini 2012) and for $P$. mariana, a spruce native to the boreal forests of Canada (Lamhamedi and Bernier 1994). The equations to describe the normalized (0-1) functional relationship between $P_{\mathrm{G}}$ and monthly temperature values are:

$$
\begin{aligned}
& f(T)=\text { If }\left(T_{\mathrm{av}} \leq T_{\min }\right) \text { or }\left(T_{\mathrm{av}} \geq T_{\mathrm{max}}\right), \text { then } f(T)=0 \\
& \text { Else } f(T)=\left(\left(T_{\mathrm{av}}-T_{\min }\right) /\left(T_{\mathrm{opt}}-T_{\min }\right)\right) \\
& \quad \times\left(\left(T_{\max }-T_{\mathrm{av}}\right) /\left(T_{\max }-T_{\mathrm{opt}}\right)\right){ }^{(T \text { max }- \text { Topt }) /(T \text { opt }-T \text { min })}
\end{aligned}
$$

\section{Averaged monthly climatic data at the study site}

A summary of mean monthly climatic conditions for the period 1957-2009 appears in Table 2. At the study site, the annual mean temperature averaged $-0.35{ }^{\circ} \mathrm{C}$ for the same period, while the average maximum temperature in July was $17.9^{\circ} \mathrm{C}$ and the average minimum temperature in January was $-23.2^{\circ} \mathrm{C}$. Total annual precipitation, averaged from the two weather stations, was $465 \mathrm{~mm}$. Less than $10 \%$ of annual precipitation falls between November and March when mean temperatures are $<-4.5^{\circ} \mathrm{C}$; this small amount probably is lost through sublimation; $86 \%$ fell in the growing season. During the growing season, temperatures averaged 8.5 and $72 \%$ of the annual incident radiation ( $4622 \mathrm{MJ} \mathrm{m}^{-2}$ ) was available to be absorbed by the canopy. The warmest years of the record was 2009 , with annual mean temperatures of $1.05^{\circ} \mathrm{C}$; the coldest years were $1962\left(-1.48{ }^{\circ} \mathrm{C}\right)$ and $1983\left(-1.43^{\circ} \mathrm{C}\right) .1962$ was the driest year, with an annual precipitation of $360 \mathrm{~mm}$, while 1989 was the wettest year $(604 \mathrm{~mm})$. Atmospheric concentrations of $\mathrm{CO}_{2}$ over the period rose $72 \mathrm{ppm}$, from 315 to 387 ppm (http://www.esrl.noaa.gov/gmd/ccgg/trends/).

\section{Statistical comparisons of trends and model sensitivity analyses}

Trends in the climatic driving variables, including $\mathrm{CO}_{2}$, were quantified using linear regression analyses to contrast 
Table 1 3-PG model parameters for Picea crassifolia used in this study

\begin{tabular}{|c|c|c|c|c|}
\hline Variables & Symbols & Units & Functions and parameter values & References \\
\hline Photosynthetic efficiency & $P_{\text {Eff }}$ & $\begin{array}{l}\mathrm{mol} \mathrm{C} \mathrm{mol}^{-1} \\
\text { photon }\end{array}$ & 0.03 & Schulze et al. (1994) \\
\hline Temperature constraints & $\begin{array}{l}T_{\mathrm{opt}}, \\
T_{\min }, \\
T_{\max }\end{array}$ & ${ }^{\circ} \mathrm{C}$ & $\begin{array}{l}T_{\min }=-2{ }^{\circ} \mathrm{C}, T_{o p t}=\left(9^{\circ} \mathrm{C}\right) \\
10{ }^{\circ} \mathrm{C}, T_{\max }=\left(30^{\circ} \mathrm{C}\right) 40^{\circ} \mathrm{C}\end{array}$ & $\begin{array}{l}\text { Tranquillini (2012), Lamhamedi and } \\
\text { Bernier (1994) }\end{array}$ \\
\hline Stocking density & - & trees $\mathrm{ha}^{-1}$ & 200 & Set to prevent self-thinning \\
\hline Leaf Area Index & $L$ & $\mathrm{~m}^{2} \mathrm{~m}^{-2}$ & $\leq 3.0$ & Tian et al. (2011) \\
\hline Max. Avail. soil water storage & $\theta_{\max }$ & $\mathrm{mm}$ & 200 and $(50-300)$ & Range analyzed \\
\hline Tree height at 100 years & - & $\mathrm{m}$ & 12.1 & Liu (1988) \\
\hline Soil texture & - & - & Clay loam & Nie et al. (2009) \\
\hline Soil fertility ranking & $N_{\mathrm{s}}$ & - & 0.10 & $\begin{array}{l}\text { Appropriate for } 0.7-0.8 \% \text { of foliar } \\
\text { nitrogen (Zhao et al. 2008) }\end{array}$ \\
\hline Allometric Eq. for stem mass & - & $\mathrm{kg}$ & $0.0685(\mathrm{dia}, \mathrm{cm})^{2.3617}$ & He et al. (2013) \\
\hline Foliage: stem partitioning ratio & - & - & 1.0 & $\begin{array}{l}\text { This study to maintain stable } L \text { at age } \\
>25 \text { years }\end{array}$ \\
\hline Foliage turnover & - & - & 0.0167 month $^{-1}, 0.20$ year $^{-1}$ & Luo et al. (2002) \\
\hline Max. age & - & years & 1000 & Set to eliminate age effect \\
\hline $\begin{array}{l}\text { Max. fraction allocated to roots as } \\
\text { function of soil fertility }\end{array}$ & - & - & 0.80 & Landsberg and Waring (1997) \\
\hline Min. fraction allocated to roots & - & - & 0.25 & Landsberg and Waring (1997) \\
\hline Wood density & - & $\mathrm{kg} / \mathrm{m}^{3}$ & 390 & Brown et al. (1949) \\
\hline
\end{tabular}

Values in brackets used in sensitivity tests

Table 2 Climatic data at the study site averaged monthly for the period 1957-2009

\begin{tabular}{|c|c|c|c|c|c|c|c|c|c|c|c|c|}
\hline Climatic variables & Jan & Feb & Mar & Apr & May & Jun & Jul & Aug & Sep & Oct & Nov & Dec \\
\hline Mean temperature $\left({ }^{\circ} \mathrm{C}\right)$ & -14.0 & -10.5 & -4.5 & 1.4 & 5.6 & 8.7 & 10.9 & 10.2 & 6.5 & 0.8 & -6.9 & -12.5 \\
\hline Maximum temperature $\left({ }^{\circ} \mathrm{C}\right)$ & -4.9 & -1.4 & 3.7 & 9.2 & 13.0 & 16.0 & 17.9 & 17.5 & 13.4 & 8.3 & 1.5 & -3.6 \\
\hline Minimum temperature $\left({ }^{\circ} \mathrm{C}\right)$ & -23.2 & -19.6 & -12.8 & -6.4 & -1.8 & 1.5 & 3.9 & 3.0 & -0.4 & -6.7 & -15.3 & -21.4 \\
\hline Precipitation (mm) & 1.5 & 2.8 & 11.2 & 23.5 & 55.3 & 77.3 & 101.8 & 96.2 & 71.0 & 20.6 & 3.4 & 1.0 \\
\hline Vapor pressure deficit $(\mathrm{kPa})$ & 0.21 & 0.26 & 0.35 & 0.49 & 0.60 & 0.70 & 0.77 & 0.77 & 0.59 & 0.45 & 0.31 & 0.22 \\
\hline Solar radiation $\left(\mathrm{MJ} \mathrm{m}^{2} /\right.$ day $)$ & 1.2 & 4.1 & 10.1 & 18.3 & 24.8 & 27.5 & 25.8 & 20.5 & 12.2 & 5.3 & 1.6 & 0.6 \\
\hline No. of rainy day (days) & 2.7 & 3.8 & 8.0 & 9.6 & 14.5 & 17.4 & 19.9 & 18.4 & 15.9 & 8.1 & 2.7 & 1.5 \\
\hline No. of frost day (days) & 30 & 30 & 30 & 24.4 & 15.2 & 8.6 & 3.9 & 5.6 & 12.3 & 24.9 & 30 & 30 \\
\hline
\end{tabular}

the two periods (1957-1979 and 1980-2009). After calibrating the model with averaged monthly climatic data (Table 2) and $\mathrm{CO}_{2}$ atmospheric concentrations set at $345 \mathrm{ppm}$ for the period 1957-2009, we conducted a series of sensitivity analyses with 3-PG to assess the relative importance of changing selected model parameter upon $P_{\mathrm{G}}$. The linear regression equations derived to describe trends in climatic variables between 1980 and 2009 served to set environmental limits for the sensitivity analyses. In addition, we evaluated the extent that changes in the parameters $\left(\theta_{\text {max }}, T_{\text {opt }}\right)$ might affect results. Our primary interests were to evaluate the relative effects of nearly a $2{ }^{\circ} \mathrm{C}$ rise in $T_{\max }$, $T_{\min }$ and $T_{\mathrm{av}}$ during the growing season between 1980 and
2009, a reduction of 18 days in frost, and a $48 \mathrm{ppm}$ increase in atmospheric concentrations of $\mathrm{CO}_{2}$.

\section{Results}

\section{Model calibration}

The allometric relationships for $P$. crassifolia, which assume $20 \%$ leaf turnover annually, and no shift in the ratio of foliage to wood production with age (Table 1), produced nearly stable values of $P_{\mathrm{G}}$ and $L$ using averaged climatic data after 50 years (Fig. 2), with $\mathrm{CO}_{2}$ set at 
$345 \mathrm{ppm}$, soil fertility at 0.1 of maximum, and $\theta_{\max }$ at $200 \mathrm{~mm}$ (Fig. 2). The period to stand closure is nearly identical to that reported for an Abies mariesii forest

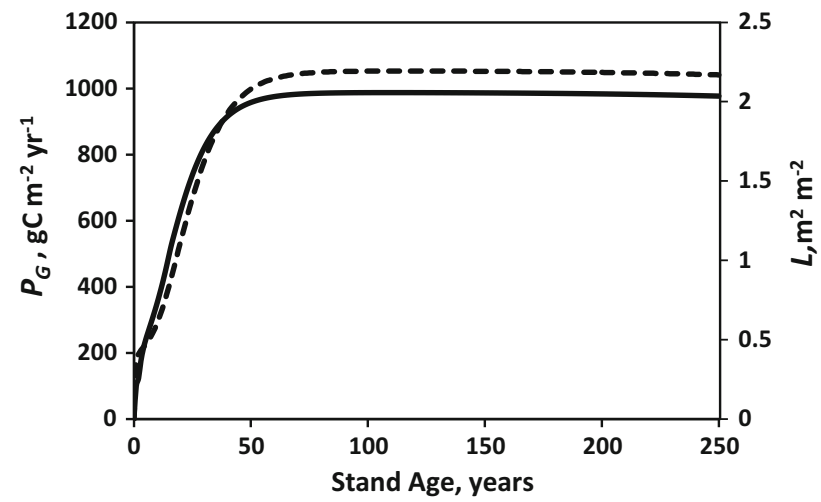

Fig. 2 3-PG model calibration run simulating gross photosynthesis $\left(P_{\mathrm{G}}\right)$ and leaf area index $(L)$, both which plateau after the Qinghai spruce stand exceeds 50 years in age using mean monthly climatic data and an average atmospheric concentration of $\mathrm{CO}_{2}$ of $345 \mathrm{ppm}$ for the period 1957-2009 (Table 2) growing near timberline in Japan (Tadaki et al. 1977). The maximum equilbrium $L$ at slightly $>2.0 \mathrm{~m}^{2} \mathrm{~m}^{-2}$ is reasonable (Tian et al. 2011), although it, along with $P_{\mathrm{G}}$, would normally be expected to decrease with increasing stand age (Waring and McDowell 2002). For the purpose of comparing age-detrended tree-ring analyses, we consider the model calibration to be suitable.

\section{Trends in growth and climatic variation}

From the full tree-ring analysis published by Gao et al. (2015) for the period 1785-2009, we derived the average growth index, along with linear trends since 1785 , 1900 and 1980 (Fig. 3). Over the most recent 30-year period, the tree-ring index increased by $60 \%$ compared to the equivalent period immediately preceding (Table 3).

The linear regression analyses between the tree-ring indices and climatic variables that we performed to determine if trends differed significantly between the two periods are presented in Table 3 and Fig. 4. None of the selected climatic variables alone was significantly

Fig. 3 Growth-ring chronology for 27 Qinghai spruce trees since 1785 . The sustained, nearly linear rate of increase between 1980 and 2009 exceeds that recorded over most of the period of 225-year record. Graph derived from Gao et al. (2015)

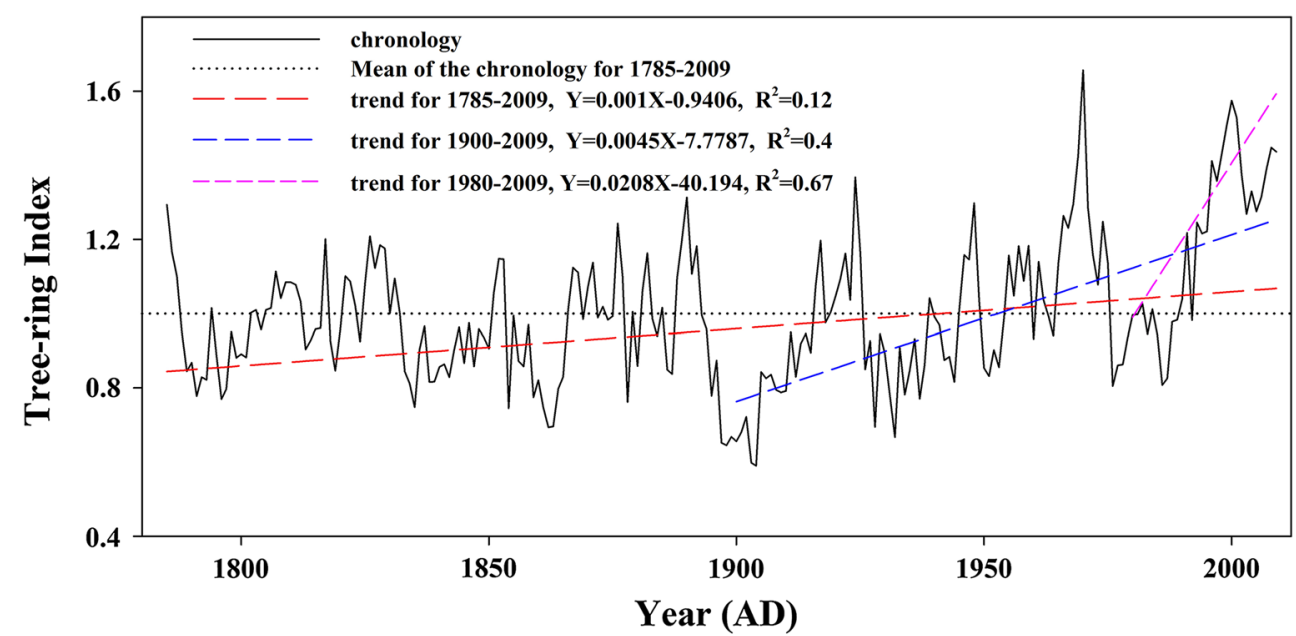

Table 3 Comparison of averages for 1957-1979 and 1980-2009 periods, with linear regression equations $(x=$ calendar year) to predict corresponding values during the 5-month growing season (GS) in 1980 and 2009

\begin{tabular}{lllllrcr}
\hline Dependent variable & $\begin{array}{l}\text { Average } \\
1957-1979\end{array}$ & $\begin{array}{l}\text { Average } \\
1980-2009\end{array}$ & Equations 1980-2009 & $r^{2}$ & Predicted 1980 & Predicted 2009 & Change \\
\hline Tree-Ring Index & 1.125 & 1.203 & $0.0208 x-40.194$ & 0.67 & 0.99 & 1.59 \\
Frost days & 50 & 42 & $-0.6071 x+1253$ & 0.53 & 50.9 & 33.3 & -17.6 \\
CO $_{2}$, ppm (annual av.) & 324 & 361 & $1.6543 x-2938.1$ & 0.99 & 337 & 385 \\
Av. mean GS Temp. & 7.33 & 7.92 & $0.0596 x-110.93$ & 0.62 & 7.08 & 8.81 \\
Av. max GS Temp. & 15.3 & 15.77 & $0.0602 x-104.32$ & 0.56 & 14.88 & 16.62 \\
Av. Min GS Temp. & 0.8 & 1.6 & $0.0628 x-123.65$ & 0.53 & 0.69 & 1.73 \\
Av. GS $D, \mathrm{kPa}$ & 0.68 & 0.69 & $0.0024 x-4.087$ & 0.32 & 0.64 & 0.75 \\
\hline
\end{tabular}



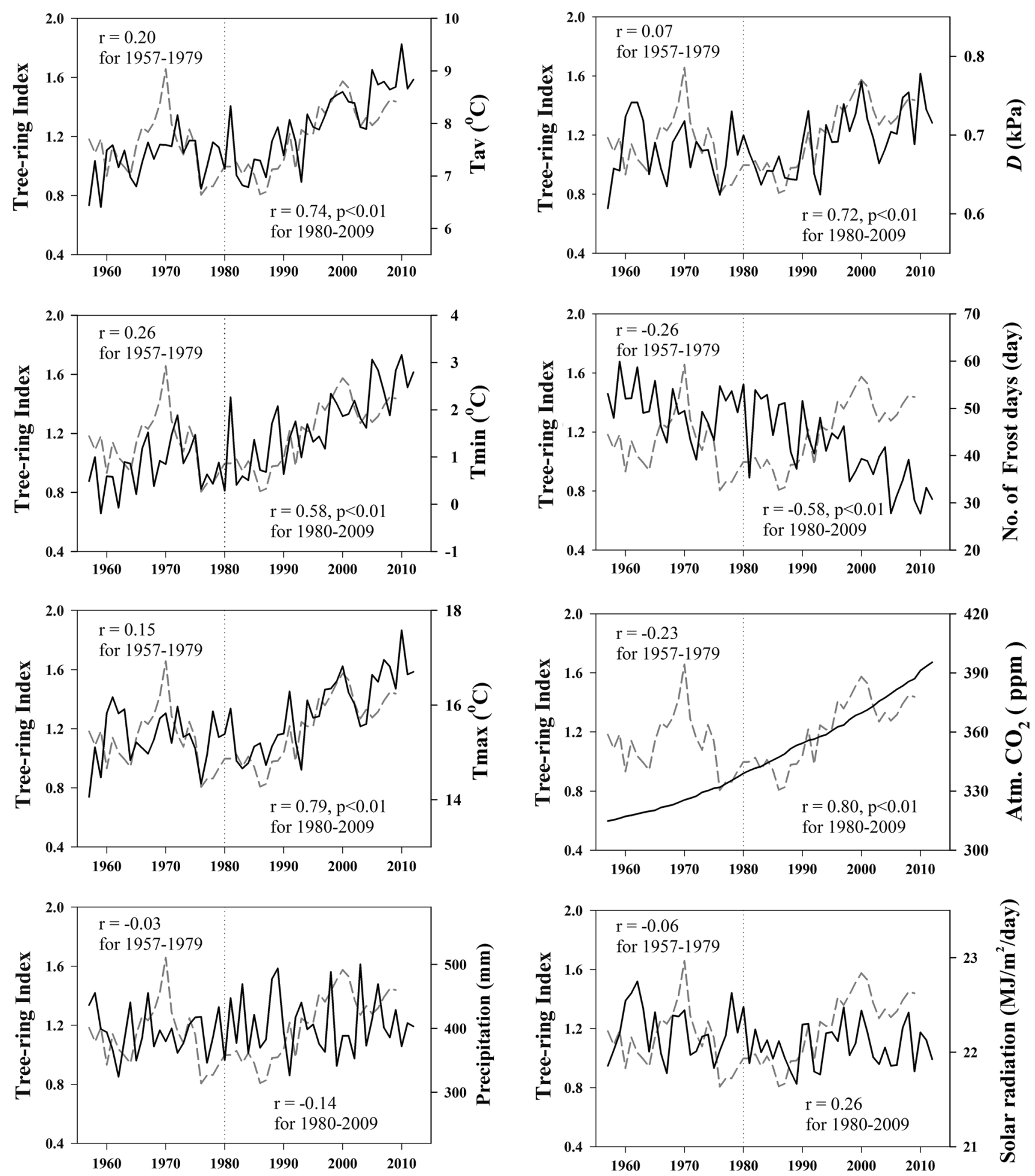

Fig. 4 Regression analyses of trends in tree-ring index and climatic variables for the two periods (1957-1979; 1980-2009). Note that none of the climatic variables were correlated significantly with the

correlated with the tree-ring index for the period 1957-1980. Since 1980, the correlation coefficients for all of the temperature variables were positive, and significant $(P<0.01)$; as was frost frequency, but with the latter

tree-growth ring index during the period 1957-1979. All but precipitation and solar radiation were significantly correlated with tree growth during the period 1980-2009

showing a negative trend $(r=-0.58)$. The tree-ring index showed a strong positive correlation $(r=0.80)$ with a $48 \mathrm{ppm}$ increase in the annual concentrations of atmospheric $\mathrm{CO}_{2}$ between 1980 and 2009 (Fig. 4). 


\section{Sensitivity analysis with 3-PG model under averaged climatic conditions}

Sensitivity analyses indicated that the $\theta_{\max }$ could vary from 50 to $300 \mathrm{~mm}$ (Table 1) under averaged climatic conditions (Table 2) without any effect on $P_{\mathrm{G}}$ (simulations not shown). Similarly, a $20 \%$ increase in growing season $D$ had no influence on $P_{\mathrm{G}}$. A decrease in $T_{\mathrm{opt}}$ from 10 to $9{ }^{\circ} \mathrm{C}$ would increase $P_{\mathrm{G}}$ by $<2 \%$ under averaged climatic conditions, and had a similar or lesser effect on the results of the comparison of exchanging 1980 with 2009 growing season temperatures shown in Table 4. Reducing $T_{\max }$ from 40 to $30{ }^{\circ} \mathrm{C}$ would increase $P_{\mathrm{G}}$ by $10 \%$ with a $T_{\mathrm{opt}}$ of $20{ }^{\circ} \mathrm{C}\left(2{ }^{\circ} \mathrm{C}\right.$ above $T_{\mathrm{av}}$ of the warmest month). It is unlikely that a $1.73{ }^{\circ} \mathrm{C}$ increase in growing season average temperature contributed significantly to the $60 \%$ increase in tree-ring growth between 1980 and 2009 (Table 3).

The largest response in $P_{\mathrm{G}}$ was generated with a change in the frequency of frost during the growing season from the beginning to the end of the last period (1980-2009).
When we reduced frost frequency by 18 days in the 1980 growing season to that predicted in 2009 (i.e., from 51 to 33 days), $P_{\mathrm{G}}$ was predicted to increase by $42 \%$ (Table 4 ). On the other hand, reversing the situation in 2009 would reduce $P_{\mathrm{G}}$ by $27 \%$. There is a strong interaction between frost and $\mathrm{CO}_{2}$. With a $48 \mathrm{ppm}$ increase in $\mathrm{CO}_{2}$ under typical 1980 climatic conditions, a $20 \%$ increase in $P_{\mathrm{G}}$ was predicted (Table 4). Reversing the situation for 2009, with only 33 days of growing season frost compared to 51 in 1980 , and a predicted reduction in $\mathrm{CO}_{2}$ from 385 to $337 \mathrm{ppm}$, would cause a $27 \%$ reduction in $P_{\mathrm{G}}$ according to our simulations (Table 4).

\section{Analysis with continuous variation in climatic conditions and atmospheric $\mathrm{CO}_{2}$}

To provide a year-to-year comparison of tree-ring analyses with diameter growth predicted by 3-PG, we activated a subroutine "Vary Block" below which entries into the columns "Age" and " $\mathrm{CO}_{2}$ " were made for the period
Table 4 Predicted changes in gross photosynthesis $\left(P_{\mathrm{G}}\right)$ in 1980 and 2009 from 3-PG
Fig. 5 Over the period from 1957 to 2009 , modeled gross photosynthesis, $P_{\mathrm{G}}$ as closely correlated with simulated growth in diameter $(r=0.985$, $P<0.01)$ and with Leaf Area Index, $L(r=0.888, P<0.01)$, but less so with the measured tree-ring index $(r=0.557$, $P<0.01)$

\begin{tabular}{llc}
\hline Variable & Simulated change & \% change in $P_{\mathrm{G}}$ \\
\hline GS temperature & a & -3 \\
GS temperature & 1980 climate with 2009 GS temperatures & 2 \\
$\mathrm{CO}_{2}$ effect & 1980 climate with $1980 \mathrm{GS}$ temperatures & 20 \\
$\mathrm{CO}_{2}$ effect & 2009 climate with $1980 \mathrm{CO}_{2}$ & -14 \\
Frost effect & 1980 climate with 2009 GS frost & 42 \\
Frost effect & 2009 climate with 1980 GS frost & -27 \\
\hline
\end{tabular}

${ }^{a} G S$ growing season (May through September)

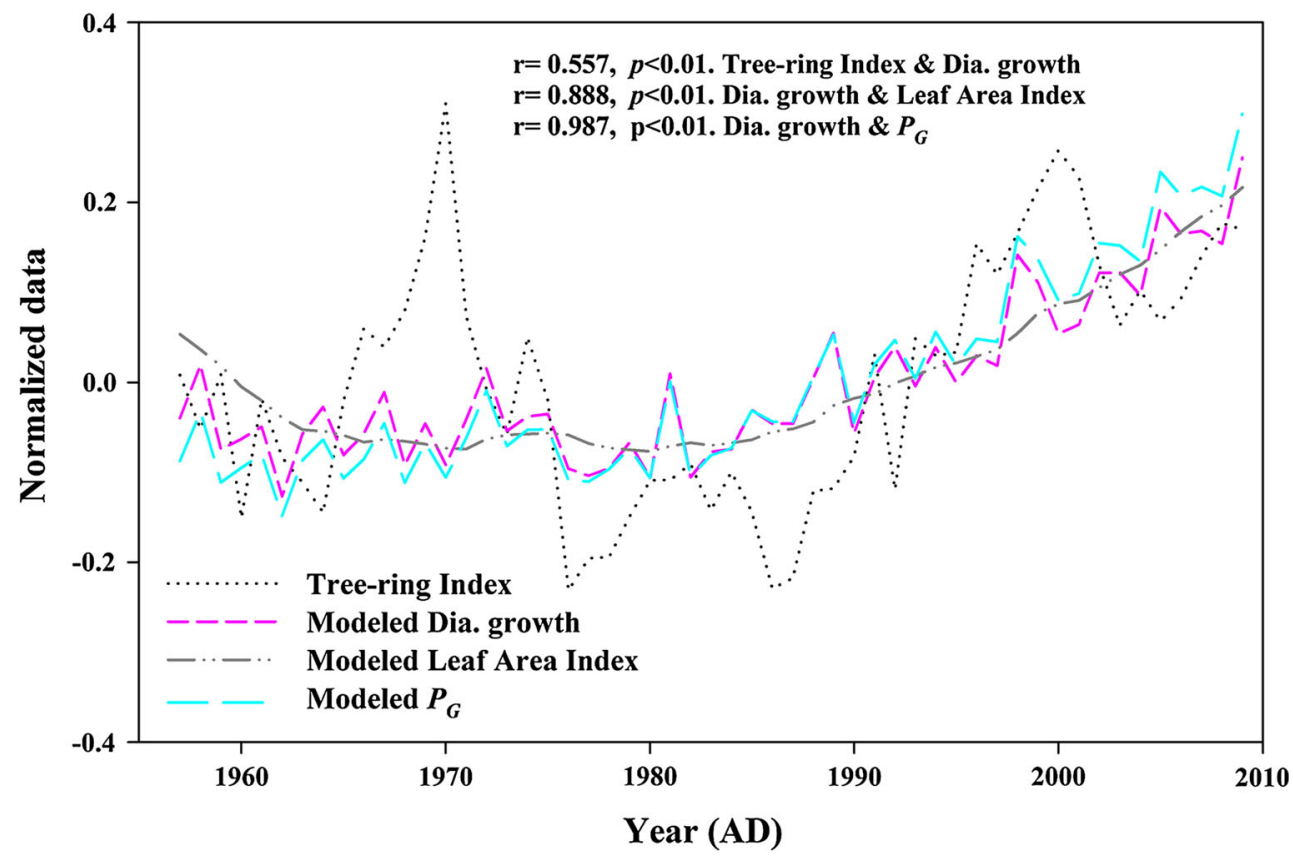


1957-2009. In addition to diameter growth, values of $P_{\mathrm{G}}$ and $L$ were generated to compare with tree-ring growth index values. To compare deviations from the mean for the four variables, we first normalized the annual entries as a fraction of the maximum recorded, then subtracted them from the mean (ranging between 0.74 and 0.78 of the maximum).

The results of the analysis are presented in Fig. 5, showing normalized values of $P_{\mathrm{G}}$ and diameter growth deviated from averaged values in nearly identical fashion ( $r=0.985, P<0.01)$. The normalized tree-ring index and 3-PG predictions of diameter growth both show a steady increase since 1980, $(r=0.701, P<0.01)$ along with an increase in simulated $L$. There is little agreement, however, between the two variables in the period from 1957 to 1979 ( $r=0.168, P$ NS).

There are no changes in the eight meteorological variables that might account for such large variation in the treering chronology before 1980 (Fig. 4). As noted by Li et al. (2014), variation among trees from different dominant classes may contribute to such a varying signal in growth rings. It is unlikely that a major disturbance to the canopy would result in a marked increase in ring growth. There is a possibility that the simulated trend in $L$ (Fig. 5), which correlate well with projected diameter growth and $P_{\mathrm{G}}$ ( $r=0.888, P<0.01$ ) can be assessed by further analyses of tree cores, an option that will be discussed in the next section.

\section{Discussion}

There are two main points that come from our analysis: (1) interpretation of simple correlations with weather data and tree growth can be misleading, and (2) by deriving a more complete set of climatic variables, it is possible to use process-based growth models to help identify causal responses in growth rates to changing environmental conditions. For example, since 1980 , both $D$ and mean maximum growing season temperatures [as well as July temperatures (Gao et al. 2015)] increased significantly $(P<0.01)$ in parallel with tree-ring indices (Fig. 4), but there was as yet no cause for a reduction in stomatal conductance or $P_{\mathrm{G}}$ because $D$ remained $<1 \mathrm{kPa}$ by 2009 (Oren et al. 1999). Most spruces however are extremely sensitive to increases in $D$ (Waring et al. 1975; Watt et al. 1976; Marchand 1984; Brubaker and Hinckley 1985), particularly at low soil temperatures (DeLucia and Smith 1987). Recently observed canopy reduction and dieback of $P$. crassifolia at lower elevations elsewhere in its range (Yu et al. 2015) are likely a response, at least initially, to increasing humidity deficits associated with warming climatic conditions.
In contrast, $\mathrm{CO}_{2}$, which has been rising steadily long before 1957, only began to appear to affect Qinghai spruce growth at the study site after 1980. This is probably because, before that time, the frequency of subfreezing nights during the growing season equaled or exceeded $40 \%$ (i.e., $\geq 60$ days out of 150 ) and severely damped any growth response to rising atmospheric concentrations of $\mathrm{CO}_{2}$ (Fig. 4). If climatic warming continues, we can extrapolate by applying Eq. (1) that once mean monthly minimum temperatures during the growing season exceed $6{ }^{\circ} \mathrm{C}$, that frost will no longer limit $P_{\mathrm{G}}$. At that time, the growing season should expand to more than 5 months (Table 2). Without frost, the maximum temperature is likely to continue to rise, increasing the evaporative demand, which, although reducing photosynthesis immediately, could still increase transpiration rates from 2 to over $3 \mathrm{~mm}$ day $^{-1}$, eventually leading to drought-stressed spruce without a reduction in growing season precipitation (simulations not shown).

The simulated $20 \%$ increase in $P_{\mathrm{G}}$ between 1980 and 2009 (Table 4) associated with a 48 ppm increase in $\mathrm{CO}_{2}$ is more than what might be expected to affect photosynthetic efficiency or tree growth (Norby et al. 2005). This additional enhancement of growth results, in the model, because the Qinghai spruce stand is assumed to have an $L<3.0$; where small increases make a big difference in the fraction of light intercepted by the canopy (Beer's Law, Eq. 2). Under 1980 climatic conditions, an increase from ambient levels of $\mathrm{CO}_{2}$ (337 ppm) to 2009 concentrations (385 ppm) was predicted to increase $L$ from 1.95 to 2.32 , equivalent to a $10 \%$ increase in light interception by the canopy, and accounted for $50 \%$ of the total simulated increase in $P_{\mathrm{G}}$ associated with the increase in atmospheric $\mathrm{CO}_{2}$ over the period (Table 4 ). The predicted increase of $L$ is within the most sensitive range of passive remote sensing instruments (White et al. 1997; Smettem et al. 2013). Such a response to increasing concentrations of $\mathrm{CO}_{2}$ is well documented (Norby et al. 2005). The full impact of rising concentrations of atmospheric $\mathrm{CO}_{2}$ upon forest ecosystems is complicated as it affects not only foliage production and turnover, but also nitrogen cycling and the partitioning of growth below ground (Norby and Luo 2004; Norby and Zak 2011). In areas where climatic warming is accompanied by drought and high vapor pressure deficits, photosynthesis will be increasingly limited, eventually leading to species replacement, regardless of the beneficial effects of increasing $\mathrm{CO}_{2}$ and reduced frequency in frost (Choat et al. 2012).

In general, it is easier to model the growth response of a forest stand than that of individual trees. Unfortunately, most dendrochronological studies do not provide information that foresters and process models require to characterize stands. It would be highly desirable to determine 
the sapwood cross-sectional areas and tree diameters for all species sampled within a specified plot area. With this additional information, the leaf growth efficiency, a measure of tree vigor, and stand $L$ can be assessed (Kaufmann and Troendle 1981; Waring 1983; Marchand 1984).

We were fortunate that $P$. crassifolia has been fairly well studied at a site where both $L(<3.0)$ and foliar nitrogen content were notably low $(<0.8 \%)$. Also, through sensitivity analyses, we were able to conclude that the observed recent increase in $D$ is probably still ineffectual, and that with normal summer precipitation $\theta_{\max }$ could vary between 50 and $300 \mathrm{~mm}$ without effect on $P_{\mathrm{G}}$ or diameter growth. We feel that the frost effect is conservatively estimated, because a subalpine spruce in Taiwan already shows much reduced photosynthesis at temperatures slightly above freezing (Weng et al. 2005). At the same time, the Taiwan spruce exhibits a very broad temperature optimum between 2 and $11{ }^{\circ} \mathrm{C}$ (Weng et al. 2005), supporting our interpretation that growth responses since 1980 are unlikely to be attributed to increases in mean growing season temperatures. We have less confidence in our assessment of the $\mathrm{CO}_{2}$ effect, particularly without more direct estimates of $L$. Although all models are simplifications of reality, they can still be helpful in separating correlations from causation. As we demonstrate, sensitivity analyses are useful in evaluating the relative importance of variables, and in identifying thresholds where effects become important.

The real goal should be the prediction of above-ground growth, which require the inclusion of allometric relations with tree diameter (Hember et al. 2015) and the recognition of possible interannual variation in wood density (Bourlaud et al. 2015), both variables specified in Table 1. Clearly, it would be advantageous to have direct measurements for all of the parameters required to initialize 3-PG or any other process-based model. When such is the case, above-ground growth can be predicted accurately even in fast-growing plantations that differ by $>20$-fold in productivity (Rodríguez et al. 2002, 2009) or have recently been fertilized and irrigated (Stape et al. 2004). In the future, we hope that process-based modeling can be applied to more sites with other tree species in China with an effort to quantify stocking density, mean tree diameters, ages, and $L$.

Although not observed at the study site, high elevation forests are becoming more vulnerable to outbreaks of native insects and pathogens where conditions are wetter and warmer, or much drier than historically was the case. Older trees, although they may have deeper root systems, are particularly vulnerable because their hydraulic systems are less efficient than trees still growing rapidly in height. Although growing conditions for Qinghai spruce appear to be improving above an elevation of $3000 \mathrm{~m}$, it is unlikely that such old trees will be resistant to attack if massive outbreaks of insects occur with further warming (Bentz et al. 2010). The hybrid approach presented in this paper offers valuable insights that indicate thresholds beyond which the effects of climatic change may shift from beneficial to conditions that may impair tree growth and threaten survival.

Author contribution statement LG conducted the field work, analyzed the tree-ring cores, and created all but Fig. 2. RW wrote the manuscript, created Fig. 2, all the tables, and did the modeling with 3-PG.

Acknowledgments We are indebted to Dr. Peter J. Sands, who developed efficient software to run the model, for instructing us in the use of the "Vary Block" subroutine that allows assessment of continuous variation in atmospheric $\mathrm{CO}_{2}$ as a function of tree age. We are appreciative of editorial suggestions made by our colleague, Chris Still on an earlier draft of the manuscript and for insightful suggestions provided by two anonymous reviewers. This research was supported by the National Science Foundation of China (No. 41171039 and No. 41475067). Linlin Gao was also funded by the China Scholarship Council. Waring's participation in this study was supported by the US National Aeronautics and Space Administration (NASA), grant No. NNX11A0296 in the program for Biodiversity and Ecological Forecasting.

\section{Compliance with ethical standards}

Conflict of interest The authors declare that they have no conflict of interests.

Open Access This article is distributed under the terms of the Creative Commons Attribution 4.0 International License (http://crea tivecommons.org/licenses/by/4.0/), which permits unrestricted use, distribution, and reproduction in any medium, provided you give appropriate credit to the original author(s) and the source, provide a link to the Creative Commons license, and indicate if changes were made.

\section{References}

Ainsworth EA, Rogers A (2007) The response of photosynthesis and stomatal conductance to rising $\mathrm{CO}_{2}$ : mechanisms and environmental interactions. Plant Cell Environ 30:258-270

Almeida AC, Sands PJ, Bruce J, Siggins AW, Leriche A, Battaglia M, Batista TR (2009) Use of a spatial process-based model to quantify forest plantation productivity and water use efficiency under climate change scenarios. 18th world IMAVS/MODSIM Congress, Cairns, Australia. http://mssanz.org.au/modsim09

Ayres MP, Lombardero MJ (2000) Assessing the consequences of global change for forest disturbance from herbivores and pathogens. Sci Total Environ 262:263-286

Bentz BJ, Régnière J, Fettig CJ, Hansen EM, Hayes JA et al (2010) Climate change and bark beetles of the western US and Canada: direct and indirect effects. Bioscience 60:602-613

Bourlaud O, Teodoslu M, Kirdyanov AV, Wirth C (2015) Influence of wood density in tree-ring based annual productivity assessments and its errors in Norway spruce. Biogeosci Discuss 12:5871-5905

Briffa KR, Schweingruber FH, Jones PD, Osborn TJ, Shiyatov SG, Vaganov EA (1998) Reduced sensitivity of recent tree-growth to temperature at high northern latitudes. Nature 391:678-682 
Brodribb TJ, Field TS (2000) Stem hydraulic supply is linked to leaf photosynthetic capacity: evidence from New Caledonian and Tasmanian rainforests. Plant Cell Environ 23:1381-1388

Brown HP, Panshin AJ, Forsaith CC (1949) Textbook of wood technology. McGraw-Hill Book Company, New York

Brubaker LB, Hinckley TM (1985) Water relations of white spruce (Picea glauca (Moench) Voss) at tree line in north central Alaska. Can J For Res 15:1080-1087

Campbell GS, Norman JM (1998) An introduction to environmental biophysics. Springer, Berlin

Campioli M, Vicca S, Luyssaert S, Bilcke J, Ceschia E, Chapin FS III, Ciais P, Pernández-Martinez M, Malhi Y, Obesteiner M, Olefeldt D, Papale D, Piao SL, Peñuelas J, Sullivan PF, Wang $\mathrm{X}$, Zenone T, Janssens IA (2015) Biomass production efficiency controlled by management in temperate and boreal ecosystems. Nat Geosci Lett. doi:10.1038/NGEO2553

Choat B, Jansen S, Brodribb TJ, Cochard H, Delzon S, Bhaskar R, Bucci SJ, Field TS, Gleason SM, Hacke UG (2012) Global convergence in the vulnerability of forests to drought. Nature 491:752-755

Constable J, Friend AL (2000) Suitability of process-based tree growth models for addressing tree response to climate change. Environ Pollut 110:47-59

Cook ER, Krusic PJ, Melvin T (2013) Program RCSigFree: Version 43ptr05. Lamont-Doherty Earth Observatory, Columbia University, Palisades

Coops NC, Waring RH, Moncrieff JB (2000) Estimating mean monthly incident solar radiation on horizontal and inclined slopes from mean monthly temperatures extremes. Int J Biometeorol 44:204-211

DeLucia EH, Smith WK (1987) Air and soil temperature limitations on photosynthesis in Engelmann spruce during summer. Can J For Res 17:527-533

Drew TJ, Flewelling JW (1977) Some recent Japanese theories of yield-density relationships and their application to Monterey pine plantations. For Sci 23:517-534

Evans MN, Reichert BK, Kaplan A, Anchukaitis KJ, Vaganov EA, Hughes MK, Cane MA (2006) A forward modeling approach to paleoclimatic interpretation of tree-ring data. J Geophys Res 111:G03008. doi:10.1029/2006JG000166

Gao LL, Gou XH, Deng Y, Liu WH, Yang MX, Zhao ZQ (2013) Climate-growth analysis of Qilian juniper across an altitudinal gradient in the central Qilian Mountains, northwest China. Trees 27:379-388

Gao LL, Gou XH, Deng Y, Yang MY, Zhang F, Li J (2015) Dendroclimatic reconstruction of temperature in the eastern Qilian Mountains, northwestern China. Clim Res 62:241-250

Gou XH, Chen FH, Jacoby G, Cook E, Yang M, Peng JF, Zhang Y (2007) Rapid tree growth with respect to the last 400 years in response to climate warming, northeastern Tibetan Plateau. Int $\mathbf{J}$ Climatol 27:1497-1503

Hadley JL (2000) Effect of daily minimum temperature on photosynthesis in eastern hemlock (Tsuga canadensis L.) in autumn and winter. Arct Antarct Alp Res 32:368-374

He QS, Chen EF, An R, Li Y (2013) Above-ground biomass and biomass components estimation using LiDAR data in a coniferous forest. Forests 4:984-1002

Hember RA, Kurz WA, Metsaranta JM (2015) Ideas and perspectives: use of tree-ring width as an indicator of tree growth. Biogeosci Discuss 12:8341-8352

Huffman GJ, Adler RF, Bolvin DT, Gu G, Nelkin EJ, Bowman KP et al (2007) The TRMM multisatellite precipitation analysis (TMPA): Quasi-global, multiyear, combined-sensor precipitation estimates at fine scales. J Hydrometeorol 8:38-55
Jones PD, Hulme M (1996) Calculating regional climatic time series for temperature and precipitation: methods and illustrations. Int $\mathbf{J}$ Climatol 16:361-377

Kaufmann MR, Troendle CA (1981) The relationship of leaf area and foliage biomass to sapwood conducting area in four subalpine forest tree species. For Sci 27:477-482

Kimbell JS, Running SW, Nemani R (1997) An improved method for estimating surface humidity from daily minimum temperature. Agric For Meteorol 85:87-98

Koch GW, Sillett SC, Jennings GM, Davis SD (2004) The limits to tree height. Nature 428:851-854

Lamhamedi MS, Bernier PY (1994) Ecophysiology and field performance of black spruce (Picea mariana): a review. Annal Scie For 51:529-551

Lamontagne M, Margolis H, Bigras F (1998) Photosynthesis of black spruce, jack pine, and trembling aspen after artificially induced frost during the growing season. Can J For Res 28:1-12

Landsberg JJ, Waring RH (1997) A generalised model of forest productivity using simplified concepts of radiation-use efficiency, carbon balance and partitioning. For Ecol Manag 95:209-228

Li G, Harrison SP, Prentice IC, Falster D (2014) Simulation of tree ring-widths with a model for primary production, carbon allocation, and growth. Biogeosciences 11:6711-6724

Liu XC (1988) Again talk about the structure law of Picea crassifolia on northern slope of Qilian Mountain. J Gansu Agric Univ 1:130-138 (in Chinese with English abstract)

Luo TX, Li WH, Zhu HZ (2002) Estimated biomass and productivity of natural vegetation on the Tibetan Plateau. Ecol Appl 12:980-997

Mäkelä A, Landsberg J, Ek AR, Burk TE, Ter-Mikaelian M, Ågren GI, Oliver CD, Puttonen P (2000) Process-based models for forest ecosystem management: current state of the art and challenges for practical implementation. Tree Physiol 20:289-298

Marchand PJ (1984) Sapwood area as an estimator of foliage biomass and projected leaf area for Abies balsamea and Picea rubens. Can J For Res 14:85-87

Melvin TM, Briffa KR (2008) A "signal-free" approach to dendroclimatic standardisation. Dendrochronologia 26:71-86

Monteith JL, Unsworth MH (1990) Principles of environmental physics. Edward Arnold, London

Nie XH, Che KJ, Liu XD, Wang H, Zhang JH (2009) Study on the main forest type soil hydrological function in the Xishui Forest Region of Qilian Mountain. J Anhui Agric Sci 37:7269-7272 (in Chinese with English abstract)

Norby RJ, Luo JY (2004) Evaluating ecosystem responses to rising atmospheric $\mathrm{CO}_{2}$ and global warming in a multi-factor world. New Phytol 162:281-293

Norby RJ, Zak DR (2011) Ecological lessons from free-air $\mathrm{CO}_{2}$ enrichment (FACE) experiments. Annu Rev Ecol Evol Syst 42:181-203

Norby RJ, DeLucia EH, Gielen B, Calfapietra C, Giardina CP, King JS et al (2005) Forest response to elevated $\mathrm{CO}_{2}$ is conserved across a broad range of productivity. Proc Natl Acad Sci USA 102:18052-18056

Oren R, Sperry JS, Katul GG, Pataki DE, Ewers BE, Phillips N, Schäfer KVR (1999) Survey and synthesis on intra-and interspecific variation in stomatal sensitivity to vapour pressure deficit. Plant Cell Environ 22:1515-1526

Raffa KF, Aukema BH, Bentz BJ, Carroll AL, Hicke JA, Turner MG, Romme WH (2008) Cross-scale drivers of natural disturbances prone to anthropogenic amplification: the dynamics of bark beetle eruptions. Bioscience 58:501-517 
Rodríguez R, Espinosa M, Real MP, Inzunza J (2002) Analysis of productivity of radiata pine plantations under different silvicultural regimes using the $3 \mathrm{PG}$ process-based model. Aust For 65:165-172

Rodríguez R, Real P, Espinosa PM, Perry DA (2009) A process-based model to evaluate site quality for Eucalyptus nitens in the BioBio Region of Chile. Forestry 82:149-162

Running SW, Nemani R, Hungerford RD (1987) Extrapolation of synoptic meteorological data in mountainous terrain, and its use for simulating forest evapotranspiration and photosynthesis. Can J For Res 17:472-483

Salzer MW, Hughes MK, Bunn ZG, Kipfmueller KF (2009) Recent unprecedented tree-ring growth at the highest elevations and possible causes. Proc Natl Acad Scie USA 106:20348-20353

Schulze E, Kelliher FM, Korner C, Lloyd J, Leuning R (1994) Relationships among maximum stomatal conductance, ecosystem surface conductance, carbon assimilation rate, and plant nitrogen nutrition: a global ecology scaling exercise. Annu Rev Ecol Syst 25:629-660

Smettem KR, Waring RH, Callow JN, Wilson M, Mu Q (2013) Satellite-derived estimates of forest leaf area index in southwest Western Australia are not tightly coupled to interannual variations in rainfall: implications for groundwater decline in a drying climate. Glob Change Biol 19:2401-2412

Stape JL, Ryan MG, Binkley D (2004) Testing the utility of the 3-PG model for growth of Eucalyptus grandis $\mathrm{x}$ urophylla with natural and manipulated supplies of water and nutrients. For Ecol Manag 260:1076-1082

Sturrock RN, Frankel SJ, Brown AV, Hennon PE, Kliejunas JT, Lewis KL, Worrall JJ, Woods AJ (2011) Climate change and forest diseases. Plant Pathol 60:133-149

Tadaki Y, Sato A, Sakurai S, Takeuchi I, Kawahara T (1977) Studies on the production struction of forest. XVII. Structure and primary production in subalpine "dead tree strips" Abies forest near Mt. A. Sahi. Jpn J Ecol 27:83-90

Tian FX, Zhao CY, Feng Z (2011) Simulating evapotranspiration of Qinghai spruce (Picea crassifolia) forest in the Qilian Mountains, northwestern China. J Arid Environ 75:648-655

Tranquillini W (2012) Physiological ecology of the Alpine Timberline. Springer, New York
Walther G-R, Post E, Convey P, Menzel A, Parmesan C, Beebee JC, Fromentin J-M, Hoegh-Guildberg O, Bairlein F (2002) Nature 416:389-394

Waring RH (1983) Estimating forest growth and efficiency in relation to canopy leaf area. Adv Ecol Res 13:327-354

Waring RH, McDowell N (2002) Use of a physiological process model with forestry yield tables to set limits on annual carbon balances. Tree Physiol 22:179-188

Waring RH, Emmingham WH, Running SW (1975) Environmental limits of an endemic spruce, Picea breweriana. Can J Bot 53:1599-1613

Warren CR, Adams MA (2000) Water availability and branch length determine $\delta^{13} \mathrm{C}$ in foliage of Pinus pinaster. Tree Physiol 20:637-643

Watt WR, Neilson RE, Jarvis PG (1976) Photosynthesis in Sitka spruce (Picea sitchensis (Bong,) Carr.): VII. Measurement of stomatal conductance and ${ }^{14} \mathrm{CO}_{2}$ uptake in a forest canopy. J Appl Ecol 13:623-638

Weng JH, Liao TS, Sun KH, Chung JC, Lin CP, Chu CH (2005) Seasonal variations in photosynthesis of Picea morrisonicola growing in the subalpine region of subtropical Taiwan. Tree Physiol 25:973-979

White JD, Running SW, Nemani R, Keane RE, Ryan KC (1997) Measurement and remote sensing of LAI in Rocky Mountain montane ecosystems. Can J For Res 27:1714-1727

Yan X, Niu SK (2008) The effects of climatic factors on pine wilt disease. For Resour Manag 4:70-76 (in Chinese with English abstract)

Yu L, Huang L, Shao X, Xiao F, Wilmking M, Zhang Y (2015) Warming-induced decline of Picea crassifolia growth in the Qilian Mountains in recent decades. PLoS One 10:e0129959

Zhang Y, Wilmking M (2010) Divergent growth responses and increasing temperature limitations of Qinghai spruce growth along an elevation gradient at the northeast Tibet Plateau. For Ecol Manag 193:219-234

Zhao CM, Chen LT, Ma F, Yao BQ, Liu JQ (2008) Altitudinal differences in the leaf fitness of juvenile and mature alpine spruce trees (Picea crassifolia). Tree Physiol 28:133-141 